\title{
Specify Other MET Exon 14 Mutation
}

National Cancer Institute

\section{Source}

National Cancer Institute. Specify Other MET Exon 14 Mutation. NCI Thesaurus. Code C158939.

A request to enter the specific MET exon 14 mutation that was identified in the study but is not present in the form. 